\title{
THE EFFECT OF URINE VOLUME ON UREA EXCRETION
}

\author{
By DONALD D. VAN SLYKE \\ (From the Hospital of the Rockefeller Institute for Medical Research, New York City)
}

(Received for publication July 16, 1947)

In recent papers Bing (1) and Williams (2) have proposed formulae which these authors believe to be more accurate than the original "standard" and "maximum" clearance equations of Möller, McIntosh, and Van Slyke $(3,4)$, in expressing the effects of urine volume flow on the urea clearance in human subjects. Both Bing and Williams base their formulae on the data of Möller et al (3).

The essential test of accuracy of such a formula is the consistency with which it permits one to calculate, from clearances shown by a subject with widely varying urine flows, the clearance that he would show with a given constant urine flow. Neither Williams nor Bing has applied such a test. In the present paper it is applied to compare their formulae with the original equations of Möller et al, with data from both normal and nephritic subjects. The theoretically derived equation of Dole (5), which was apparently overlooked by both Williams and Bing, is also included in the comparison, and tentative conclusions are drawn concerning permeability changes in the renal tubules in chronic nephritis.

\section{CLEARANCE FORMULAE}

Maximum and standard clearance formulae of Austin et al (6), and Möller et al (3). Simultaneous observations of urea excretion rates, urine volumes, and blood urea concentrations made by Austin et al (6) and by Möller, et al (3) showed that the urea clearance, defined as the volume of blood containing the amount of urea excreted in 1 minute, was but little affected by urine flow changes in normal human subjects when the flow (per 1.73 sq. m. body area) exceeded an "augmentation limit" which was usually about $2 \mathrm{cc}$. per minute, but that when the urine flow fell below this limit the urea clearance fell with the urine flow, the clearance then becoming proportional approximately to the square root of the flow. Chesley $(7,8)$ confirmed the square root rule for urine flows down to about 0.35 cc. per minute, but found that when extreme dehydration reduced urine flow below this rate, further reduction in flow was accompanied by a more rapid fall in urea clearance, which then fell in direct proportion to the urine flow, rather than to its square root.

The above empirically observed effects of urine volume on the urea clearance in the 3 respective urine flow ranges are expressed by Equations 1,2 and 3, in which $C_{v}$ represents the clearance calculated as $U V / B$, for any urine volume flow $V$ (in cc. per minute), and $U$ and $B$ indicate the concentrations of urea in urine and blood respectively.

When $V$ exceeds the augmentation limit of about 2:

1. $C_{v}=C_{m}=$ constant for each subject.

$C_{m}$ is the "maximum clearance" of Möller et al (3), and averages $\mathbf{7 5}$ for normal adults. ${ }^{1}$

When $V$ is between the augmentation limit and $0.5 \mathrm{cc}$. per minute:

2.

$$
C_{v}=C_{1} \sqrt{V} .
$$

$C_{1}$, the clearance when $V=1$, was called the "standard clearance" by Möller et al (3), who found that it averaged 54 for normal adults.

Chesley's formula for maximal urine concentration. When $V$ is less than $0.35 \mathrm{cc}$. per minute the value of $C_{v}$ approximates that expressed by Chesley's $(7,8)$ formula:

$$
\text { 3. } \quad C_{v}=R_{m} \times V \text {. }
$$

$R_{m}$ is a constant, the maximum $U / B$ ratio attainable by decreasing urine flow to its minimum. The average normal value of $R_{m}$ is about 75. (In nephritis the value of $R_{m}$ may fall to 3 or 4 (9) and be reached with urine volumes above $1 \mathrm{cc}$. per minute [see Table IV].)

Dole's equation. Dole (5) has derived an equation, based on estimation of tubular urea reabsorption in accordance with Fick's diffusion law, which covers the effects of all ranges of urine flow.? Dole's equation is:

$$
\text { 4. } \quad C_{v}=C_{m} / e^{b / V}=C_{m} / \operatorname{antilog} 10 \frac{b^{\prime}}{V} \text {. }
$$

1 Correction for body size in any clearance equation is made by using as $V$ corrected, the observed $V$ multiplied by the factor, $1.73 /$ (sq. meters body area), in the calculation of $C_{v}$ as $U V / B$, and wherever $V$ appears elsewhere in the equation. It has been shown (10) that clearances vary in direct proportion to body area in human subjects above the age of 1 year, and that the correction can be made by applying the factor $1.73 / \mathrm{m}^{2}$. to $V, 1.73$ being taken as the average adult surface area.

${ }^{2}$ Dole expressed his equation as $C_{v}=F \times \phi \times e^{-k / V}$, where $F$ is the amount of urea filtered per minute, $\phi$ is the fraction (about 0.60 ) that escapes reabsorption in the first fraction of the tubular segments, and $e^{-k / V}$ is the part of that fraction that escapes reabsorption in the final tubule and achieves excretion as urine. In terms of the maximal clearance, $C_{m}=F \times \phi$, and $C_{v}$ approaches $C_{m}$ when $V$ becomes so large that $e^{-k / V}$ approaches unity. In Equation 4 we have written $C_{m}$ in place of $F \times \phi$, and have used $b$ to indicate specifically the constant $k$ in the 
$C_{m}$, as in Equation 1, signifies the maximal clearance obtained with large urine volume flow. Dole's equation is based on the assumptions: (1) that a constant fraction (normally about $\mathbf{4 0}$ per cent) of the urea in the glomerular filtrate diffuses back into the blood from the lumina of the proximal tubules with the "obligatively" reabsorbed water (which is estimated to be about 90 per cent of that filtered); (2) that in a second section of the tubule further reabsorption of water, with negligible reabsorption of urea, brings the filtrate to its final volume (the urine volume, $V$ ); (3) that during passage of a third tubular segment a second fraction of the filtered urea is reabsorbed, without water, into the blood by passive diffusion, this fraction being calculable by Fick's diffusion law from the permeability of the tubular wall of this segment for urea and the final volume of the filtrate. $C_{m}$ represents the cc. of blood that would be cleared of urea per minute if, of the total urea filtered in the glomeruli the approximately 60 per cent that escapes reabsorption in the proximal tubules were all excreted, while the fraction $1 / e^{b / V}$ is the fraction of the 60 per cent that finally attains excretion after part has been reabsorbed in the third segment. The constant, $b$, is the product of the surface area of the walls of the third segments and their permeability for urea, which Dole estimates to be of the order of 0.001 of the permeability of erythrocytes for urea. The constant $b^{\prime}$ in Equation 4 is $b$ multiplied by 0.4343 to change from exponent of $e$ to exponent of 10 . If $b$ has a high value in a given subject the effect of urine volume change on clearance is high, and vice versa.

We have estimated the approximate mean normal values of $C_{m}$ and $b^{\prime}$ of Equation 4 as 80 and 0.17 , respectively, from the data on the 6 normal subjects in Table II of Möller et al (3). The value, 80, calculated for mean normal $C_{m}$ of Equation 4, is higher than the $C_{m}$ value of 75 , estimated by Equation 1 as the mean of clearances observed with urine volumes above an "augmentation limit" of about $2 \mathrm{cc}$. per minute. The Dole equation assumes that the clearance increases asymptotically to a maximum reached at higher urine output; hence this calculated maximum is greater than the mean observed in the $V$ range above $2 \mathrm{cc}$.

As Dole points out, individual and pathological variations in $b$ may be expected. However, application of Dole's equation to the normal data of Möller et al (3) and to their data from patients with Bright's disease indicates that in both normal and nephritic human subjects one can calculate for each subject fairly constant results for $C_{m}$ from observed $C_{v}$ and $V$ values by assuming a value of 0.17 for $b^{\prime}$ in all the subjects.

factor $e^{-k / v}$. The equation $C_{v}=F \times \phi \times e^{-k / v}$, with $\phi$ assumed to be constant, is a simplified form of a more complete equation developed by Dole in which the value of $\phi$ is expressed as a function of the volume of filtrate escaping "obligative" reabsorption in the first segment. The mean normal value of $\phi$ is estimated as the ratio, (urea clearance with maximal urine flow): (inulin clearance), which is about 0.60 in normal men. It is usually about the same in nephritis, but may be nearer unity (11).
Williams' formula. Williams (2), from the data of Möller et al (3) on normal subjects, evolved the equation: $(U / B)^{1.103} \mathrm{~V}=K$. This can be transformed into:

5.

$$
C_{v}=C_{1} V^{0.093} \text {, }
$$

where $C_{1}$, as in Equation 2, indicates the value of $C_{v}$ when $V=1, C_{1}$ being 54 for the average normal subject.

Bing's formula. Bing (1) believes that the most accurate calculation of $C_{m}$ can be made by estimating tubular reabsorption of urea, not from $V$, but from the ratio, $U / B$, as indicated by Equation 6 , the factor $f$ being a function of $U / B$ that Bing estimated from the data of Möller et al (3) on normal subjects. For plotting the curve of $f$ against $U / B$, Bing gives the following pairs of simultaneous values for $U / B$ and $f$, respectively: $U / B 1$ to 20 , $f=1 ; 30,1.15 ; 40,1.30 ; 50,1.43 ; 60,1.54 ; 70,1.60$; $80,1.64$. With values of $f$ varying from 1 to 1.64 according to $U / B$, Bing's formula is:

6.

$$
C_{v}=C_{m} / f
$$

Although Bing introduced his formula to replace $V$ by $U / B$ as a factor determining $C_{v}$, it can be shown that Bing's $f$ is in fact a function of $V$. By plotting the logarithms of $U / B$ against the logarithms of the corresponding $f$ values given by Bing, a straight line is obtained, the equation of which is $f=\left(\frac{U}{20 B}\right)^{0.37}=0.33(U / B)^{0.37}$, and which gives Bing's $f$ values within \pm 2 per cent, for values of $U / B$ over 20 ( $f$ being 1 when $U / B<20$ ). Substituting $0.33(U / B)^{0.37}$ for $f$ in Equation 6, and solving for $C_{v}=\frac{U V}{B}$ gives, as an expression of Bing's formula applicable when $U / B$ exceeds 20:

7.

$$
C_{v}=2.24 C_{m}^{0.73} V^{0.27} \text {. }
$$

When $C_{m}$ has the average normal value of 75 , the equation becomes:

8.

$$
C_{v}=52.4 V^{0.27} \text {. }
$$

The value, 52.4 , for $V=1$, approximately agrees with the normal $C_{1}$ of 54 found by Möller et al (3).

Equation 8 is used in Figure 1 to include Bing's formula in the comparison of the effects of $V$ change calculated by the different formulae for a subject of average normal clearance.

\section{COMPARISON OF RESULTS BY DIFFERENT FORMULAE}

Data used. Möller and McIntosh provide data on 6 normal subjects (3), for each of whom 12 to 20 clearances were determined with urine volumes varying over the widest ranges obtainable by varying the fluid intake, and for 6 nephritics with varying degrees of abnormally lowered urea clearance, for each of whom from 9 to 26 clearances were determined with similarly varied urine volume flows. These data are used to compute Tables I to IV. As an 
additional normal subject, $\mathrm{H}$. A. from a previous paper (6) is added: H. A. provides 20 clearances with $V$ values well distributed over a wide range.

Procedure for comparison. To compare the relative accuracies with which the different formulae estimate the effect of $V$ or $U / B$ on $C_{v}$, values of the maximum clearance, $C_{m}$, obtainable by high urine flow for each subject, are calculated by the different formulae from the $C_{v}$ values obtained with the various observed flows. For each individual the standard percentage deviation is computed of the $C_{m}$ values calculated by each formula from the mean $C_{m}$ of the subject calculated by that formula. It is assumed that the most accurate formula will be the one that yields the smallest average percentage deviation from the means.

By any of the formulae except that of Bing, one could calculate $C_{1}$ (clearance when $V=1$ ) or the clearance at any other $V$, instead of $C_{m}$. Bing's formula (Equation 6), however, applied as given by its author, serves only for calculation of the maximum clearance as a function of $U / B$.

The self-evident rearrangements of Equations 1,4 and 6 to calculate $C_{m}$ are indicated in the column headings of Tables I and II.

For calculation of $C_{m}$ by the square root relation expressed in Equation 2, the relation is expressed as

$$
\text { 9. } \quad C_{m}=C_{v} \sqrt{\frac{A}{V}} \text {, }
$$

where $A$ is the augmentation limit of $V$, and is assumed to be a constant. $A$ is taken as the $V$ value at which both Equation 1 and Equation 2 indicate the same $C_{v}$ value. If the mean normal values of $C_{m}$ and $C_{1}$ viz. 75 and 54, are inserted in Equations 1 and 2, respectively, both equations give the same value for $C_{v}$ when $V=1.93$. We have therefore used 1.93 as a constant value for $A$. Substituting 1.93 for $A$ in Equation 9 gives:

$$
\text { 10. } C_{m}=C_{v} \sqrt{\frac{1.93}{V}}=1.39 C_{v} / \sqrt{V} \text {. }
$$

Equation 10 is used to compute values for the clearances by the formula of Möller, McIntosh and Van Slyke (3) in Tables I to IV for urine volumes below $1.93 \mathrm{cc}$. per minute. The assumption of 1.93 as a constant augmentation limit for all the subjects, normal and nephritic, introduces a variable error, since, as shown in the original papers $(3,4)$, the augmentation limit varies somewhat from subject to subject. The results in Tables I to IV indicate, however, that the error from assumption of a constant value for $A$ is not great in either normal or nephritic subjects. The possible explanation for the apparent fact that the reduction of renal function in nephritis may not greatly affect the augmentation limit will be discussed later.

To estimate $C_{m}$ by Williams' formula (Equation 5) we have calculated, from observed $C_{v}$ values, the clearance for a urine flow of $20 \mathrm{cc}$. per minute. As shown by Figure 1, Williams formula for the average normal subject indicates a clearance, when $V$ approaches 20 , that approximates the $75 \mathrm{cc}$. value found by direct observation (3) as the average normal $C_{m}$. Also a urine flow of $20 \mathrm{cc}$. per minute is about the maximum obtainable by water diuresis.

Letting $C_{20}$ indicate the clearance obtained when $V=20$, we have from Equation 5, according to Williams:

$$
C_{20}: C_{v}=(20 / V)^{0.093}=1.32 / V^{0.093},
$$

whence:

$$
\text { 11. } \quad C_{20}=1.32 C_{v} / V^{0.093} \text {. }
$$

The $C_{20}$ calculated by Equation 11 is given in tables as the $C_{m}$ calculated by Williams' formula.

\section{RESULTS OF COMPARISONS}

The means and standard deviations of the series of normal subjects of Möller, McIntosh, and Van Slyke (3) are given in Table I, those of their nephritic subjects (4) in Table II. Tables III and IV give the complete data on normal subject H. A., and on the nephritic, Gia, who showed the lowest clearance values of the group in Table II.

The relative accuracies of the different formulae applied to 3 normal subjects are illustrated by Figure 1. The curves are calculated for the hypothetical average normal adult; they represent $C_{v}$ values calculated by the indicated equations with mean normal values for their constants. Subject H. A. is a normal man whose constants closely approximate these values. The points for very low urine volumes are taken 


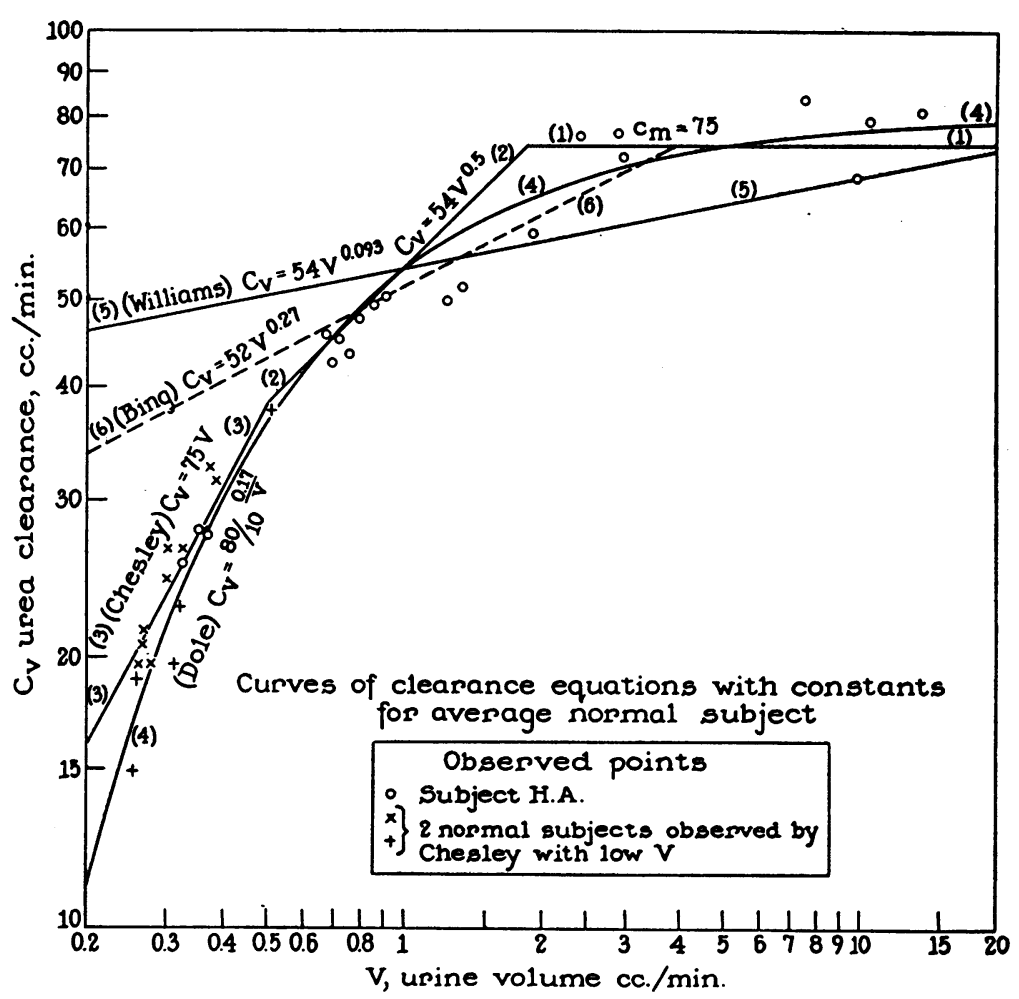

Fig. 1. Comparison of Observed Relation of Urea Clearance and Urine Volume with Relations Calculated by the Indicated Formulae FOR the Average Normal Subject. The number in parentheses on each curve indicates the number of the equation, in the text, by which the curve is calculated.

from data of Chesley (8) on 2 subjects who gave $R_{m}$ values approximating 75 . The curves illustrate the facts that Dole's theoretical equation appears to apply adequately to all urine volumes, that the 3 empirical equations of Möller et al (3) and Chesley $(7,8)$ represented by the broken-line curve, 1-2-3, fit approximately within their respective ranges of urine flow, and that the Bing and Williams formulae are less accurate, especially for low urine flows.

From Tables I and II it is evident that $C_{m}$ values calculated by the formulae of Bing and Williams show consistently for each subject, both normal and nephritic, greater standard deviations from the mean of the subject than do $C_{m}$ values calculated by the original "maximum" and "standard" clearance formulae of Möller, McIntosh and Van Slyke (3), or by the equation of Dole (5).

Tables III and IV show how the errors of both the formula of Bing and that of Williams are particularly great when these formulae are applied to clearances observed with low urine flows, where error in relating maximal water reabsorption to urea reabsorption in the tubules becomes most apparent.

That the standard deviations of individual $C_{m}$ values in Tables I and II are not significantly greater for $C_{m}$ calculated by the formulae of Möller et al than by Dole's equation, is attributable to the fact that but few of the urine flows in the observations recorded were below $0.5 \mathrm{cc}$. per minute. The results confirm Dole's conclusion with regard to clinical use of clearance formulae, that "the 'maximal' and 'standard' urea clearance formulae are adequate for their purposes, except for conditions of unusually small urine flows."

The conclusions concerning the relative accuracy of the "maximum" and "standard" clearance formulae compared with Williams' exponential formula reached by the above analysis 
TABLE I

Normal subjects. Variability of maximal urea clearance, $C_{m}$, calculated from observed
clearance, $C_{v}$, by different formulae ${ }^{*}$

Figures in parentheses indicate percentage of average normal $C_{m} \cdot \dagger$

\begin{tabular}{|c|c|c|c|c|c|c|c|c|c|}
\hline \multirow{3}{*}{$\begin{array}{l}\text { Subject and } \\
\text { no. of } \\
\text { observations }\end{array}$} & \multirow{3}{*}{$\begin{array}{c}\text { Range of } \\
\text { urine } \\
\text { volume } V\end{array}$} & \multicolumn{8}{|c|}{ Formulae } \\
\hline & & \multicolumn{2}{|c|}{$\begin{array}{c}\text { M. M. and } \mathrm{V}_{\dot{ }} \mathrm{S} .(3) \\
C_{\mathrm{m}}=C \text { when } V>1.93 \\
C_{m}=1.39 C_{v} / \sqrt{V} \\
\text { when } V<1.93\end{array}$} & \multicolumn{2}{|c|}{$\begin{array}{c}\text { Bing (1) } \\
C_{m}=C_{*} \text { when } U / B<20 \\
C_{m}=f C_{\text {v }} \text { when } U / B>20\end{array}$} & \multicolumn{2}{|c|}{$\begin{array}{c}\text { Williams (2) } \\
C_{20}=1.32 C_{v} / V^{0.083}\end{array}$} & \multicolumn{2}{|c|}{$\begin{array}{c}\text { Dole (5) } \\
C_{m}=C_{\text {D Xantilog }} \\
0.17 \\
V\end{array}$} \\
\hline & & $\underset{C_{m}}{\text { Mean }}$ & $\begin{array}{l}\text { St. dev. } \\
\text { from mean }\end{array}$ & $\underset{C_{m}}{\text { Mean }}$ & $\begin{array}{l}\text { St. dev. } \\
\text { from mean }\end{array}$ & $\underset{C_{m}}{\text { Mean }}$ & $\begin{array}{l}\text { St. dev. } \\
\text { from mean }\end{array}$ & $\underset{C_{m}}{\text { Mean }}$ & $\begin{array}{l}\text { St. dev. } \\
\text { from mean }\end{array}$ \\
\hline L. L. & $\begin{array}{l}c c . \text { per } \\
0.47 \text { to } \\
12.33\end{array}$ & $\begin{array}{c}79 \\
(105)\end{array}$ & $\begin{array}{l}\text { per cent } \\
\pm 14.5\end{array}$ & \begin{tabular}{|c|} 
cc. per minute \\
83 \\
$(111)$
\end{tabular} & $\begin{array}{l}\text { per cent } \\
\pm 14.3\end{array}$ & $\begin{array}{c}\text { cc. per minute } \\
79 \\
(111)\end{array}$ & $\begin{array}{l}\text { per cent } \\
\pm 21.1\end{array}$ & $\begin{array}{c}\text { cc. per minute } \\
86 \\
(108)\end{array}$ & $\begin{array}{l}\text { per cent } \\
\pm 12.2\end{array}$ \\
\hline J. F. M. & $\begin{array}{l}0.60 \text { to } \\
8.58\end{array}$ & $\begin{array}{l}68 \\
(91)\end{array}$ & \pm 12.7 & $\begin{array}{l}70 \\
(93)\end{array}$ & \pm 17.4 & $\begin{array}{c}71 \\
(100)\end{array}$ & \pm 19.3 & $\begin{array}{l}75 \\
(94)\end{array}$ & \pm 12.0 \\
\hline A. $\mathrm{H}$. & $\begin{array}{l}0.57 \text { to } \\
10.83\end{array}$ & $\begin{array}{c}64 \\
(85)\end{array}$ & \pm 10.3 & $\begin{array}{c}66 \\
(88)\end{array}$ & \pm 22.0 & $\begin{array}{l}67 \\
(94)\end{array}$ & \pm 22.9 & $\begin{array}{c}71 \\
(89)\end{array}$ & \pm 14.1 \\
\hline W. N. & $\begin{array}{l}0.37 \text { to } \\
12.50\end{array}$ & $\begin{array}{c}71 \\
(95)\end{array}$ & \pm 13.6 & $\begin{array}{c}73 \\
(97)\end{array}$ & \pm 24.1 & $\begin{array}{c}70 \\
(99)\end{array}$ & \pm 22.1 & $\begin{array}{c}78 \\
(97)\end{array}$ & \pm 14.1 \\
\hline V.S. & $\begin{array}{l}0.50 \\
16.25\end{array}$ & $\begin{array}{c}83 \\
(111)\end{array}$ & \pm 11.3 & $\begin{array}{c}86 \\
(115)\end{array}$ & \pm 14.6 & $\begin{array}{c}82 \\
(115)\end{array}$ & \pm 19.9 & $\begin{array}{c}90 \\
(113)\end{array}$ & \pm 11.8 \\
\hline J. C. B. & $\begin{array}{l}0.80 \text { to } \\
12.47\end{array}$ & $\begin{array}{c}61 \\
(81)\end{array}$ & \pm 10.2 & $\begin{array}{c}59 \\
(79)\end{array}$ & \pm 14.6 & $\begin{array}{c}65 \\
(92)\end{array}$ & \pm 16.4 & $\begin{array}{c}65 \\
(81)\end{array}$ & \pm 11.6 \\
\hline H. A. & $\begin{array}{l}0.32 \text { to } \\
13.40\end{array}$ & $\begin{array}{c}72 \\
(96)\end{array}$ & \pm 9.2 & $\begin{array}{c}71 \\
(95)\end{array}$ & \pm 19.4 & $\begin{array}{c}69 \\
(97)\end{array}$ & \pm 24.9 & $\begin{array}{c}80 \\
(100)\end{array}$ & \pm 7.2 \\
\hline Mean & & $\begin{array}{c}71 \\
(95)\end{array}$ & \pm 11.8 & $\begin{array}{l}72 \\
(96)\end{array}$ & \pm 16.5 & $\begin{array}{c}72 \\
(101)\end{array}$ & \pm 21.0 & $\begin{array}{c}79 \\
(99)\end{array}$ & \pm 11.8 \\
\hline
\end{tabular}

* Figures for first 6 subjects include all the data on Table II of Möller, McIntosh, and Van Slyke (3), except one obviously erroneous clearance of W. N. Data on H. A. are from Austin, Stillman, and Van Slyke (6).

$\dagger$ Average normal values assumed are 75 for $C_{m}$ by the equations of M. M. and V.S. and Bing, 71 for $C_{20}$ calculated from $C_{1}$ of 54 by Williams' equation, 80 for $C_{m}$ by Dole's.

are contrary to the conclusion of Williams based on the same data, in so far as the normal subjects are concerned, which were the only group considered by Williams. The difference appears to be due to different statistical procedures used by Williams and by ourselves in estimating the accuracy of the respective formulae. Williams calculated $V$ from observed values of $U / B$ both by his formula and by the "maximum" and "standard" clearance formulae (Equations 1 and 2), using for all subjects average normal values of the constants of the respective equations. He calculated as $d$ for each equation the mean difference between the $V$ values thus calculated and the observed $V$ values. His formula gave the lower mean $d$, and he therefore concluded that it was the more accurate. In these calculations Williams used for all subjects as constants the values of $C_{1}$ or $C_{m}, v i z .54$ and 75 , found by Möller et al (3) as the average for normal adults. Thus the equations used (from Equations 5, 1 and 2, respectively) to calculate $V$ were: $V=\left(54 \frac{B}{U}\right)^{1.103}$ (Williams [2]), $V=\frac{75 B}{U}$ (Möller et al for $V$ over 1.93) and $V=\left(54 \frac{U}{B}\right)^{2}$ (Möller et $\left.a l\right)$ for $V<1.93$. The use of the same $C_{m}$ and $C_{1}$ values for every subject of the group introduces errors into the $V$ values calculated when the actual $C_{m}$ and $C_{1}$ of any subject deviate from 75 and 54 , and are 
TABLE II

Nephritic patients. Variability of maximal urea clearance, $C_{m}$, calculated from observed clearance, $C_{v}$, by different formulae. Data of Möller, McIntosh and Van Slyke (4)

Figures in parentheses indicate percentages of average normal.*

\begin{tabular}{|c|c|c|c|c|c|c|c|c|c|c|c|c|}
\hline \multirow{4}{*}{ Subject } & \multirow{4}{*}{$\begin{array}{c}\text { Range of } \\
\text { urine } \\
\text { volumes } \\
V \dagger\end{array}$} & \multicolumn{11}{|c|}{ Formulae } \\
\hline & & \multirow{2}{*}{\multicolumn{2}{|c|}{$\begin{array}{c}\text { M. M. and V. S. (3) } \\
C_{m}=C_{v} \text {. } \\
\text { when } V>1.93 \\
C_{m}=1.39=C_{v} / \sqrt{V} \\
\text { when } V<1.93\end{array}$}} & \multirow{2}{*}{\multicolumn{2}{|c|}{$\begin{array}{c}\text { Bing (1) } \\
C_{m}=C_{v} \\
\text { when } U / B<20 \\
C_{m}=f C_{v} \\
\text { when } U / B>20\end{array}$}} & \multirow{2}{*}{\multicolumn{2}{|c|}{$C_{m} \underset{=1.32 C_{v} / V^{0.003}}{\text { Williams }}$}} & \multicolumn{5}{|c|}{$\begin{array}{c}\text { Dole (5) } \\
C_{m}=C_{v} \times \operatorname{antilog} \frac{b^{\prime}}{V}\end{array}$} \\
\hline & & & & & & & & \multicolumn{2}{|c|}{$\begin{array}{l}\text { With } b^{\prime}=0.17 \\
\text { for all subjects }\end{array}$} & \multicolumn{3}{|c|}{$\begin{array}{l}\text { With estimated best } b^{\prime} \\
\text { for each subject }\end{array}$} \\
\hline & & $\underset{C_{m}}{\text { Mean }}$ & $\begin{array}{c}\text { St. dev. } \\
\text { from } \\
\text { mean } \\
C_{m}\end{array}$ & $\underset{C_{m}}{\text { Mean }}$ & $\begin{array}{c}\text { St. dev. } \\
\text { from } \\
\text { mean } \\
C_{m}\end{array}$ & $\underset{C}{\text { Mean }}$ & $\begin{array}{c}\text { St. dev. } \\
\text { from } \\
\text { mean } \\
C_{m}\end{array}$ & $\underset{C_{m}}{\text { Mean }}$ & $\begin{array}{c}\text { St. dev. } \\
\text { from } \\
\text { mean } \\
C_{m}\end{array}$ & $b^{\prime}$ & $\underset{C_{m}}{\text { Mean }}$ & $\begin{array}{c}\text { St. dev. } \\
\text { from } \\
\text { mean } \\
C_{m}\end{array}$ \\
\hline & \multicolumn{2}{|c|}{ cc. per minute } & per cent & $\begin{array}{l}c c . \text { per } \\
\text { minute }\end{array}$ & per cent & $\begin{array}{l}c c \text {. per } \\
\text { minute }\end{array}$ & per cent & $\begin{array}{l}c c . \text { per } \\
\text { minute }\end{array}$ & per cent & & $\begin{array}{l}c c \text { per } \\
\text { minute }\end{array}$ & per cent \\
\hline Chi. & $\begin{array}{l}0.28 \text { to } \\
9.27\end{array}$ & $\begin{array}{c}85 \\
(113)\end{array}$ & \pm 12.3 & $\begin{array}{c}78 \\
(104)\end{array}$ & \pm 23.8 & $\begin{array}{c}74 \\
(104)\end{array}$ & \pm 26.0 & $\begin{array}{c}97 \\
(121)\end{array}$ & \pm 13.0 & 0.13 & 85 & \pm 9.3 \\
\hline $\begin{array}{r}\text { Jac. } \\
24\end{array}$ & $\begin{array}{l}0.32 \text { to } \\
6.37\end{array}$ & $\begin{array}{l}31.3 \\
(39)\end{array}$ & \pm 8.0 & $\begin{array}{l}24.8 \\
(33)\end{array}$ & \pm 25.7 & $\begin{array}{l}29.8 \\
(42)\end{array}$ & \pm 24.4 & $\begin{array}{l}34.3 \\
(43)\end{array}$ & \pm 8.5 & 0.19 & 36.0 & \pm 8.4 \\
\hline $\begin{array}{r}\text { Cic. } \\
18\end{array}$ & $\begin{array}{l}0.39 \text { to } \\
5.07\end{array}$ & $\begin{array}{l}24.8 \\
(31)\end{array}$ & \pm 18.9 & $\begin{array}{l}19.3 \\
(26)\end{array}$ & \pm 32.2 & $\begin{array}{l}23.2 \\
(33)\end{array}$ & \pm 29.4 & $\begin{array}{l}27.3 \\
(34)\end{array}$ & \pm 18.9 & 0.21 & 30.2 & \pm 14.3 \\
\hline $\begin{array}{r}\text { Val. } \\
26\end{array}$ & $\begin{array}{l}0.66 \text { to } \\
5.99\end{array}$ & $\begin{array}{l}17.4 \\
(22)\end{array}$ & \pm 12.1 & $\begin{array}{l}13.3 \\
(18)\end{array}$ & \pm 13.0 & $\begin{array}{l}16.7 \\
(23)\end{array}$ & \pm 8.5 & $\begin{array}{l}18.7 \\
(23)\end{array}$ & \pm 9.6 & 0.09 & 15.6 & \pm 7.1 \\
\hline $\begin{array}{c}\text { Wol. } \ddagger \\
20\end{array}$ & $\begin{array}{l}0.81 \text { to } \\
3.55\end{array}$ & $\begin{array}{l}11.7 \\
(14.6)\end{array}$ & \pm 17.0 & $\begin{array}{c}11.2 \\
(14.9)\end{array}$ & \pm 21.9 & $\begin{array}{c}13.7 \\
(19.3)\end{array}$ & \pm 19.3 & $\begin{array}{l}13.6 \\
(17)\end{array}$ & \pm 15.2 & 0.33 & 16.3 & \pm 14.5 \\
\hline $\begin{array}{r}\text { Gia. } \\
14\end{array}$ & $\begin{array}{l}0.71 \text { to } \\
3.96\end{array}$ & $\begin{array}{l}11.0 \\
(14.7)\end{array}$ & \pm 10.9 & $\begin{array}{c}8.7 \\
(11.6)\end{array}$ & \pm 22.3 & $\begin{array}{l}11.1 \\
(15.6)\end{array}$ & \pm 18.2 & $\begin{array}{c}12.1 \\
(15.1)\end{array}$ & \pm 11.1 & 0.24 & 14.1 & \pm 9.5 \\
\hline \multicolumn{3}{|c|}{ Mean standard deviation } & \pm 12.7 & & \pm 23.1 & & \pm 21.0 & & \pm 11.6 & 0.20 & & \pm 10.5 \\
\hline
\end{tabular}

* See footnote $\dagger$ of Table I.

$\dagger$ Values of $V$ are corrected for body size by multiplying observed $V$ by the factor $1.73 /$ sq. meter surface area (10). $\ddagger$ One clearance of subject Wol. is omitted from the calculations because of obvious error in the data.

particularly large when the square root formula is applied, because with this formula the error of the calculated $V$ increases as the error of the square of the assumed $C_{1}$. In the case of normal subject J. C. B. (3), with a $C_{1}$ value of 41 , the use of 54 yields calculated $V$ values with a plus error of almost 100 per cent. Such errors could be cancelled only by the use of a large series of subjects. The statistical procedure of Williams compares the results obtained by adding errors from 2 sources: (1) the error of each formula in expressing the relation of $V$ to $C_{v}$, and (2) the error caused by using the group constant for each subject. The difference between his results and ours appears attributable to predominance of errors from the second source in his calculated $V$ values.
Significance of non-decrease of the augmentation limit and the constant, $\mathrm{b}$, of Dole's equation in nephritic subjects as indication of increased tubular permeability to urea

It was a matter of surprise to Möller et al (4) to find that in patients with glomerular nephritis and markedly reduced clearances the augmentation limit was usually of the same order of magnitude as in normal subjects. If the disease process affected renal function by inactivation of part of the nephrons, corresponding to the destroyed glomeruli seen histologically, while the remaining nephrons functioned normally, one might expect that the augmentation limit would fall parallel with the number of functioning nephrons, and hence with the clearance. 
TABLE III

Maximal urea clearance of a normal subject calculated from observed clearances with different urine volume flows

(Subject H. A. [6])

\begin{tabular}{|c|c|c|c|c|c|}
\hline \multirow{2}{*}{$\begin{array}{c}\text { Urine } \\
\text { volume } \\
V\end{array}$} & \multirow{2}{*}{$\begin{array}{l}\text { Observed } \\
\text { clearance } \\
C_{\bullet}=\frac{U V}{B}\end{array}$} & \multicolumn{4}{|c|}{$\begin{array}{c}\text { Maximal clearance, } C_{m} \text {, calculated by } \\
\text { different formulae from } \\
\text { observed clearances }\end{array}$} \\
\hline & & $\begin{array}{c}\text { Equa- } \\
\text { tions of } \\
\text { M. M. } \\
\text { and V.S. } \\
(3)\end{array}$ & $\begin{array}{l}\text { Formula } \\
\text { of Bing } \\
\text { (1) }\end{array}$ & $\begin{array}{c}\text { Equa- } \\
\text { tion of } \\
\text { Williams } \\
(2)\end{array}$ & 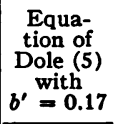 \\
\hline \multicolumn{2}{|c|}{ cc. per minute } & $\begin{array}{l}c c \text { per } \\
\text { minute }\end{array}$ & $\begin{array}{l}c c \text {. per } \\
\text { minute }\end{array}$ & $\begin{array}{l}c c \text {. per } \\
\text { minute }\end{array}$ & $\begin{array}{l}c c \text {. per } \\
\text { minute }\end{array}$ \\
\hline $\begin{array}{c}0.326 \\
.355 \\
.368 \\
.674 \\
.694 \\
.722 \\
.756 \\
.800 \\
.826 \\
.917 \\
1.26 \\
1.35 \\
1.925 \\
2.46 \\
2.95 \\
2.99 \\
7.50 \\
9.64 \\
10.40 \\
13.40\end{array}$ & $\begin{array}{l}25.5 \\
26.3 \\
27.6 \\
45.9 \\
42.5 \\
45.1 \\
43.5 \\
47.8 \\
47.4 \\
50.5 \\
60.0 \\
51.8 \\
59.6 \\
76.2 \\
77.0 \\
72.5 \\
84.0 \\
68.8 \\
79.5 \\
81.4\end{array}$ & $\begin{array}{l}62 \\
65 \\
64 \\
78 \\
71 \\
74 \\
70 \\
74 \\
72 \\
73 \\
74 \\
62 \\
60 \\
76 \\
77 \\
72 \\
84 \\
69 \\
79 \\
81\end{array}$ & $\begin{array}{l}42 \\
45 \\
45 \\
74 \\
66 \\
70 \\
66 \\
72 \\
73 \\
75 \\
85 \\
66 \\
69 \\
89 \\
84 \\
87 \\
84 \\
69 \\
79 \\
81\end{array}$ & $\begin{array}{l}37 \\
40 \\
40 \\
63 \\
58 \\
61 \\
58 \\
64 \\
64 \\
67 \\
77 \\
66 \\
74 \\
92 \\
92 \\
86 \\
93 \\
74 \\
84 \\
84\end{array}$ & $\begin{array}{l}84 \\
79 \\
80 \\
83 \\
75 \\
78 \\
73 \\
78 \\
76 \\
78 \\
82 \\
69 \\
73 \\
90 \\
88 \\
83 \\
88 \\
72 \\
83 \\
84\end{array}$ \\
\hline \multicolumn{2}{|c|}{$\begin{array}{l}\text { Mean: } \\
\text { cc. per minute } \\
\text { Per cent of average } \\
\text { normal }\end{array}$} & $\begin{array}{l}72 \\
96\end{array}$ & $\begin{array}{l}71 \\
95\end{array}$ & $\begin{array}{l}69 \\
97\end{array}$ & $\begin{array}{r}80 \\
100\end{array}$ \\
\hline \multicolumn{2}{|c|}{$\begin{array}{l}\text { Standard deviation } \\
\text { from mean: } \\
\text { cc. per minute } \\
\text { per cent of mean. }\end{array}$} & $\begin{array}{l} \pm 6.6 \\
\pm 9.2\end{array}$ & $\begin{array}{l} \pm 13.8 \\
\pm 19.4\end{array}$ & $\begin{array}{l} \pm 17.2 \\
\pm 24.9\end{array}$ & $\begin{array}{l} \pm 5.8 \\
\pm 7.2\end{array}$ \\
\hline
\end{tabular}

From the same conception one would expect the constant, $b$, of Dole's equation to fall parallel with the clearance. This constant is defined by Dole as the product, $b=a \times h$, where $a$ represents the total area of the walls of the distal segments of the functioning tubules and $h$ represents the permeability of the walls of the distal segments for urea. Destruction of part of the nephrons, and consequent decrease in the area, $a$, would result in a proportional decrease in $b$, unless the permeability, $h$, were increased in the tubules that remained functioning. It appears probable that such a permeability increase occurs, and provides an explanation of 2 aspects of renal function in advanced nephritis, viz. (1) the maintenance of the augmentation limit near the normal 2 cc. of urine per minute, and of the $b$ constant at normal, or even higher than normal levels, in many cases, and (2) the inability of the damaged kidneys to excrete urine with high urea concentration.

We have estimated values of $b^{\prime}$ of Equation 4 for the 6 nephritic patients of Table II by plotting smoothed curves of $C_{v}$ against $V$, and using values of $C_{v}$ and $V$ from points on the upper and lower parts of each curve, respectively, to calculate by simultaneous equations the constants, $C_{m}$ and $b^{\prime}$ of Equation 4. The results are given in the last 3 columns of Table II. Only in case Wol. is the $b^{\prime}$ value markedly lower than in normal subjects, and the average, 0.20 , is higher than the value 0.17 found as the mean for the normal subjects in Table I. In patient Val., despite the fact that the nephritis was so far advanced that the urea clearance was only $\frac{1}{5}$ of normal, the augmentation limit was so high that urine volumes up to $3.5 \mathrm{cc}$. per minute failed to locate the limit, and the $b^{\prime}$ value, 0.33 , was twice the normal. One might deduce that the permeability of the functioning tubules for urea was 10-fold normal.

The apparent reason for such behavior is that these tubular segments (presumably the distal),

TABLE IV

Maximal urea clearances of nephritic patient Gia. calculated from observed clearances with different urine volume flows

\begin{tabular}{|c|c|c|c|c|c|c|c|}
\hline \multirow{3}{*}{$\begin{array}{c}\text { Urine } \\
\text { vol- } \\
\text { ume } \\
V\end{array}$} & \multirow{3}{*}{$\begin{array}{c}\text { Ob- } \\
\text { served } \\
\text { clear- } \\
\text { ance } \\
C_{0}=\frac{U V}{B}\end{array}$} & \multirow{3}{*}{$\frac{U}{B}$} & \multicolumn{5}{|c|}{$\begin{array}{l}\text { Maximal clearance, } C_{m} \text {, calculated by different } \\
\text { formulae from observed clearances }\end{array}$} \\
\hline & & & \multirow{2}{*}{$\begin{array}{c}\text { Equa- } \\
\text { tion of } \\
\mathbf{M . M} \text {. } \\
\text { and } \\
\text { V.S. } \\
\text { (3) }\end{array}$} & \multirow{2}{*}{$\begin{array}{l}\text { Formula } \\
\text { of Bing } \\
\text { (1) }\end{array}$} & \multirow{2}{*}{$\begin{array}{c}\text { Equa- } \\
\text { tion of } \\
\text { Wil- } \\
\text { liams } \\
(2)\end{array}$} & \multicolumn{2}{|c|}{$\begin{array}{l}\text { Equation of } \\
\text { Dole (5) }\end{array}$} \\
\hline & & & & & & $\begin{array}{l}\text { With } \\
b^{\prime}=\overline{1} \\
0.17\end{array}$ & $\begin{array}{l}\text { With } \\
b^{\prime}= \\
0.24\end{array}$ \\
\hline \multicolumn{2}{|c|}{ cc. per minute } & ratio & \multicolumn{2}{|c|}{ cc. per minute } & \multicolumn{3}{|c|}{ cc. per minute } \\
\hline $\begin{array}{l}0.71 \\
0.76 \\
0.85 \\
0.88 \\
0.92 \\
0.92 \\
0.97 \\
0.99 \\
1.11 \\
2.17 \\
3.20 \\
3.96\end{array}$ & $\begin{array}{r}5.58 \\
6.76 \\
7.62 \\
7.04 \\
8.01 \\
8.46 \\
7.50 \\
9.07 \\
9.70 \\
10.11 \\
12.20 \\
12.00\end{array}$ & $\begin{array}{l}8.0 \\
8.9 \\
9.0 \\
8.6 \\
8.7 \\
9.2 \\
7.7 \\
9.1 \\
8.7 \\
4.8 \\
3.8 \\
3.1\end{array}$ & \begin{tabular}{r|}
9.2 \\
10.8 \\
11.3 \\
10.4 \\
11.6 \\
12.3 \\
10.6 \\
11.7 \\
12.8 \\
10.1 \\
12.2 \\
12.0
\end{tabular} & $\begin{array}{l}\text { Same as } C_{0} \\
\text { Same as } C \\
\text { Same as } C_{0} \\
\text { Same as } C_{0} \\
\text { Same as } C_{0} \\
\text { Same as } C_{0} \\
\text { Same as } C_{0} \\
\text { Same as } C_{0} \\
\text { Same as } C_{0} \\
\text { Same as } C_{0} \\
\text { Same as } C_{0}\end{array}$ & $\begin{array}{r}7.6 \\
9.1 \\
10.2 \\
9.4 \\
10.7 \\
11.2 \\
9.9 \\
12.0 \\
12.7 \\
12.4 \\
14.4 \\
13.9\end{array}$ & $\begin{array}{r}9.7 \\
11.3 \\
12.1 \\
11.0 \\
12.3 \\
12.9 \\
11.2 \\
13.5 \\
13.8 \\
12.2 \\
13.8 \\
13.3\end{array}$ & $\begin{array}{l}12.2 \\
14.0 \\
14.6 \\
13.2 \\
14.6 \\
14.6 \\
13.2 \\
14.8 \\
15.9 \\
13.0 \\
14.5 \\
13.8\end{array}$ \\
\hline \multicolumn{3}{|c|}{$\begin{array}{l}\text { Mean: } \\
\text { cc. per minute } \\
\text { per cent of average } \\
\text { normal }\end{array}$} & $\begin{array}{l}11.0 \\
14.7\end{array}$ & $\begin{array}{r}8.7 \\
11.5\end{array}$ & $\begin{array}{l}11.1 \\
15.6\end{array}$ & $\begin{array}{l}12.1 \\
15.1\end{array}$ & $\begin{array}{l}14.1 \\
17.6\end{array}$ \\
\hline \multicolumn{3}{|c|}{$\begin{array}{l}\text { Standard deviation } \\
\text { from mean: } \\
\text { cc. per minute } \\
\text { per cent of mean }\end{array}$} & $\begin{array}{l}1.20 \\
10.9\end{array}$ & $\begin{array}{l} \pm 1.94 \\
\pm 22.3\end{array}$ & $\begin{array}{l} \pm 2.02 \\
\pm 18.2\end{array}$ & $\begin{array}{l} \pm 1.34 \\
\pm 11.1\end{array}$ & $\begin{array}{l} \pm 1.34 \\
\pm 9.5\end{array}$ \\
\hline
\end{tabular}


where urea reabsorption is variable in the still functioning nephrons, are damaged in such a manner that they have an increased permeability to urea, so that urea concentration in the urine issuing from them must be kept at a lower level than in the normal tubule in order to prevent reabsorption of urea from becoming significant. In order to keep the urea concentration at the necessary lower level the volume of urine issuing per minute from each tubule must be kept greater than in the normal tubule. The permeability of the tubules approaches that observed by Richards (12) in the kidneys of frogs poisoned with mercuric chloride, in which the permeability was so increased that, although glomerular filtration appeared even more active than normal, the filtrate was completely reabsorbed in the tubules, with resultant anuria.

By maintaining a sufficiently large urine volume the nephritic kidney can apparently prevent the reabsorption of urea from exceeding the 40 per cent observed in the normal human kidney when urine flows exceed about 2 cc. per minute, but in order to prevent greater reabsorption the nephritic kidney must maintain a higher ratio of urine flow to glomerular filtrate than the normal kidney.

As a consequence of this condition, the $U: B$ ratio of urea concentrations at the augmentation limit does not remain, in the nephritic kidney, at the normal level 20:1 as assumed by
Bing (1), but falls progressively as the functioning tubules become more damaged, e.g., in the case in Table IV the $U: B$ appears to be in the neighborhood of 3 or 4 when urine flow nears the augmentation limit.

\section{Significance of urine volume in maintaining elimination by the nephritic kidney}

Lashmet and Newburgh (13) and Marriott (14) have emphasized that in nephritis maintenance of a large flow of urine is necessary when ability to concentrate is decreased. Figure 2 indicates how a study of the urea clearance with different urine volumes in the individual patient can indicate the volume output that is needed to approximate maximal efficiency of urea excretion. Cases Val. and Wol. both had about the same urea clearance, 20 per cent of normal when their urine volumes were as high as $4 \mathrm{cc}$. per minute. When the urine flows of the 2 patients were diminished, however, they showed markedly different effects. Val. maintained his clearance at approximately the same level until the urine output fell to about $1.2 \mathrm{cc}$. per minute, while in the case of Wol., fall of urine volume to $1.2 \mathrm{cc}$. per minute was accompanied by a drop of 40 per cent in the urea clearance below its value when urine flow was 3 or $4 \mathrm{cc}$. It appears that in Val. a daily excretion of 1.7 liters per 24 hours (1.2 cc. per minute) sufficed to obtain nearly

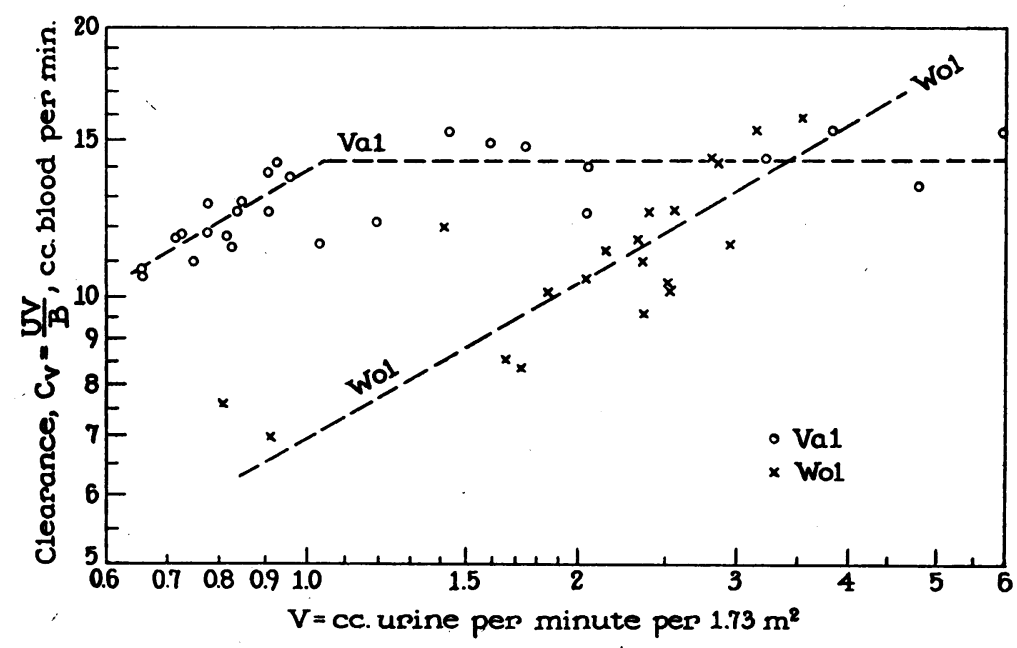

Fig. 2. Different Effects of Urine Volume Flow on Urea Clearance in 2 Nephritic Patients 
maximal efficiency of urea excretion, while in Wol. 3 times as great a volume was needed.

\section{SUMMARY}

The "maximum" and "standard" urea clearance formulae of Möller, McIntosh, and Van Slyke have been compared with formulae proposed by Bing, by Williams, and by Dole for estimating the effect of urine volume on urea clearance. The accuracy of the respective formulae has been estimated by comparing the constancy with which the maximal clearance, obtainable with high urine volume, could be calculated from clearances observed with lower urine volumes by the respective formulae for each of a number of normal and nephritic subjects.

The formulae of Bing and of Williams proved to be less accurate than those of Möller et al and of Dole.

The conceptions of Dole's theoretically derived formula have been used to explain, from increased permeability of damaged renal tubules, the different effects of urine volume on urea excretion in different nephritic subjects, and the loss in nephritis of ability to excrete urine of high urea concentration.

Examples are given indicating that, by observing the effect of urine volume on urea clearance in nephritic patients, it may be possible to estimate the urine volume flow required for optimal urea excretion.

\section{BIBLIOGRAPHY}

1. Bing, J., The calculation of urea clearance with varying degrees of urine concentration. Acta Med. Scand., 1946, 126, 199.
2. Williams, E. M. V., Urea excretion by rabbits. J. Physiol., 1946, 105, 223.

3. Möller, E., McIntosh, J. F., and Van Slyke, D. D. Studies of urea excretion; relationship between urine volume and rate of urea excretion by normal adults. J. Clin. Invest., 1928, 6, 427.

4. Möller, E., McIntosh, J. F., and Van Slyke, D. D. Studies of urea excretion; relationship between urine volume and rate of urea excretion by patients with Bright's disease. J. Clin. Invest., 1928, 6, 485.

5. Dole, V. P., Back diffusion of urea in the mammalian kidney. Am. J. Physiol., 1943, 139, 504.

6. Austin, J. H., Stillman, E., and Van Slyke, D. D., Factors governing the excretion rate of urea. J. Biol. Chem., 1921, 46, 91.

7. Chesley, L. C., The validity of the calculation of standard urea clearances from low urine volumes. J. Clin. Invest., 1937, 16, 652.

8. Chesley, L. C., Urea excretion at low urine volume. The calculation of minimal urea clearance. J. Clin. Invest., 1938, 17, 119.

9. Van Slyke, D. D., McIntosh, J. F., Möller, E., Hannon, R. R., and Johnston, C., Studies of urea excretion; comparison of the blood urea clearance with certain other measures of renal function. J. Clin. Invest., $1930,8,357$.

10. McIntosh, J. F., Möller, E., and Van Slyke, D. D., Studies of urea excretion. III. The influence of body size on urea output. J. Clin. Invest., 1928, $6,467$.

11. Chasis, H., and Smith, H., The excretion of urea in normal men and in subjects with glomerulonephritis. J. Clin. Invest., 1938, 17, 347.

12. Richards, A. N., Direct observations of changes in function of the renal tubule caused by certain poisons. Tr. A. Am. Physicians, 1927, 44, 64.

13. Lashmet, F. H., and Newburgh, L. H., A comparative study of the excretion of water and solids by normal and abnormal kidneys. J. Clin. Invest., 1932, 11, 1003.

14. Marriott, H. L., Water and salt depletion. Brit. Med. J., 1947, pp. 245, 285 and 328. 